\title{
Bioethanol Production from Indica IR.64 Rice Straw Biomass by Direct Saccharification and Fermentation
}

\author{
Ario Betha Juanssilfero ${ }^{\# 1}$, Apridah Cameliawati Djohan ${ }^{\#}$, Awan Purnawan ${ }^{\#}$ and Yopi ${ }^{\#}$ \\ \# Indonesian Institute of Sciences (LIPI) \\ Research Center for Biotechnology, Cibinong Science Center, Cibinong, Bogor, West Java 16911 \\ E-mail:1'ario002@lipi.go.id
}

\begin{abstract}
Lignocellulosic substances such as agricultural wastes are attractive feed stocks for bioethanol production. Indica IR.64 rice straw is one of abundant agricultural wastes in Indonesia and could be used to bioethanol production. It has several characteristics such as high content of cellulose and hemicelluloses that can be readily hydrolyzed into fermentable sugars. A simple process (the direct saccharification and fermentation process) to produce ethanol from rice straw was developed in order to establish an efficient bioethanol production. In this work, no harsh pre-treatment steps were applied and also use a simple one-vat reactor without the risk of losing liberated carbohydrate. The first step in using rice straw for bioethanol production is size reduction through milling and sieving process prior to enzymatic hydrolysis. Direct saccharification and fermentation (DSF) of Indica IR.64 rice straw was examined and compared with two type of control (systems devoid of yeast and enzyme). The experiment were carried out under anaerobic condition, where the cellulase crude enzyme and cellulosic substrates (rice straw) produced glucose from the cellulose and Saccharomyces cerevisiae directly assimilated the glucose to bioethanol. The faster rate of bioethanol production during DSF by Saccharomyces cerevisiae was obtained within the first $12 \mathrm{~h}$. The maximum ethanol concentration, ethanol yield, and theoretical ethanol yield of untreated rice straw were $0.25 \mathrm{~g} / \mathrm{L}, 10$ and $14.88 \%$, respectively. Nevertheless, the direct saccharification and fermentation shows the potential for lower cost and higher efficiency for bioethanol production.
\end{abstract}

Keywords - Bioethanol; Rice straw; Direct saccharification and fermentation; Lignocellulosic waste.

\section{INTRODUCTION}

At present were are living in a situation where the world's demand for energy continues to increase at a predicted rate of $1.8 \%$, especially as countries develop, while at the same time the supply of energy appears limited. To prevent a looming energy crisis, the development of renewable energy sources is becoming a priority. Renewable energy sources can provide a constant supply of energy, and examples are hydroelectricity, wind, wave power, and biological-based fuels.

In term of biological based fuel, bioethanol is an increasingly important alternative for the replacement of fossil fuel, with a world production of 19,535 millions of gallons in 2009 [1]. Bioethanol made from lignocellulosic biomass including agricultural, forestry residues and woody crops, is finally being recognized widely as a unique alternative fuel with powerful economic, environmental and strategic attributes [2] and currently became a focus in the bioenergy research field.

Lignocellulosic ethanol has recently been produced from agricultural wastes (straw and baggase), which are low cost feedstock and available in plenty and also does not have the ethical concerns associated with the use of potential food resources [2].

Rice straw is one of the most favourable feed stocks for bioethanol production due to their availability throughout the year. Indonesia is one of the major producers of rice straw in the world. The utilization fraction of rice straw is too low and varies with geographic region. Each year a large portion of agricultural residues (rice straw) is disposed as a waste. For instance, approximately 600-900 million tons per year rice straw is produced globally [3]. The options for the disposal of rice straw are limited by great bulk of material, slow degradation in the soil, harbouring of rice stem diseases, and high mineral content. Only a small portion of globally produced rice straw is used as animal feed, the rest is removed from the field by burning, a common practice all over the world. This could increase air pollution and affecting human health. As climate change is extensively recognized as a threat to development there is growing interest in alternative uses of agro-industrial residues for energy applications. In this context, rice straw would be a potential candidate for our future energy needs. 
Rice straw has several characteristics that make it a potential fed stock for fuel ethanol production. It has high cellulose and hemicelluloses content that can be readily hydrolysed into fermentable sugars. In terms of chemical composition, the straw predominantly contains cellulose (32-47\%) hemicelluloses (19-27\%) and lignin (5-24\%) [4], [5], [6], [7]. The pentoses are dominant in hemicelluloses, in which xylose is the most important sugar (14.8-20.2\%) [5], [8].

The technologies for the conversion of lignocellulosic feedstocks to ethanol have been grouped into two broad platforms, which can be referred to as the sugar platform (biochemical conversion) and the syngas platform (thermochemical conversion). In this study, we focus to applied biochemical conversion to produce bioethanol from rice straw. The biochemical conversion consists of three main process elements: production of saccharolytic enzymes, hydrolysis to monomeric sugars and fermentation.

The objective of this study is to utilize abundant lignocellulosic biomass (rice straw) for production of bioethanol. Another objective of this study is to obtain costeffective processing and to improve the product yield. This condition can be achieved by applying direct saccharification and fermentation (DSF) process. The saccharification of the lignocellulosic biomass by the enzymes and the subsequent fermentation of the sugars to ethanol by yeast take place in a single reactor in DSF process. The DSF gives higher reported yield and requires lower amounts of enzyme because end-product inhibition from cellobiose and glucose formed during enzymatic hydrolysis is relieved by the yeast fermentation [9], [10]. It should be noted that in this process no harsh pretreatment steps and use a simple one reactor without the risk of losing liberated carbohydrates.

\section{MATERIALS AND METHOD}

\section{A. Rice Straw}

The Indica IR.64 rice straw was obtained from commercial farm in Bogor, Jawa Barat, Indonesia and was harvested at the mature stage. A wet sample of approximately $5 \mathrm{~kg}$ was collected in June 2014 and immediately dried at $65^{\circ} \mathrm{C}$ for 3 days (to the final moisture $3-5 \%$ ). The rice straw was milled with a high-speed milling machine (Black \& Decker, FX 350, England). Then, the milled samples gradually screened with a sieve shaker 80 , 100 and 200- $\mu \mathrm{m}$-mesh, respectively. The screened materials were stored in desiccators until their use. The composition of rice straw was determined before the experiment.

B. Enzyme

\section{1) Culture Collection}

Cellulolytic isolate Saccharopolyspora flava used in this experiment from Biotechnology Culture Collection (BTCC). The medium for reviving is ISP2 and the composition for 1 Liter medium are $10 \mathrm{~g}$ malt extract, $4 \mathrm{~g}$ yeast extract, $5 \mathrm{~g}$ cellulose substrate (Carboxymetyl cellulose, Sigma).

2) Crude Enzyme Production.
The potential isolate Saccharopolyspora flava were produce spesific crude enzyme such as cellulase inoculated into ISP2 medium with spesific carbon sources $(5 \mathrm{~g} / \mathrm{L}$ Carboxymetyl cellulose, Sigma). The preculture process was incubated in shaker incubator with condition $30^{\circ} \mathrm{C}, 150 \mathrm{rpm}$ for 24 hours and the production culture was incubated for 72 hours in the same medium and condition. Crude enzymes resulted after centrifuge the medium at $10.000 \mathrm{rpm}, 4^{\circ} \mathrm{C}$ for $10 \mathrm{~min}$ and collect the supernatant.

\section{3) Enzyme Assays}

Enzyme activity were assayed as follows: a reaction mixture containing $0.5 \mathrm{~mL}$ of $0.5 \%$ Xylan substrate in 50 $\mathrm{mM}$ phosphate buffer $\mathrm{pH} 6.0$ as well as $0.5 \mathrm{~mL}$ of enzyme solution in the same buffer was incubated at room temperature for $30 \mathrm{~min}$, the addition of $1.5 \mathrm{~mL}$ DNS reagent for deactivated the enzyme catalytic activity then measured the solution by spectrophotometer (Shimadzu, Kyoto Japan) at $540 \mathrm{~nm}$ in wavelength. The resulting reducing power was determined by dinitrosalicylic acid (DNS) modification method [11] and using xylose as a standard. One unit of the cellulase activity was defined as the amount of enzyme liberating $1 \mu \mathrm{mol}$ of reducing sugar per minute under the above condition.

\section{Yeast Pre-culture Medium}

Pre-culture medium (yeast medium) contains $0.3 \mathrm{~g} / \mathrm{L}$ malt extract, $0.3 \mathrm{~g} / \mathrm{L}$ peptone, $0.3 \mathrm{~g} / \mathrm{L}$ yeast extract, $10 \mathrm{~g} / \mathrm{L}$ glucose. Culture medium then incubated at $30^{\circ} \mathrm{C}, 200 \mathrm{rpm}$, for 48 hours.

\section{Fermentation}

The hydrolysis broth medium was modified by using rice straw as the substrate with final concentration $5 \mathrm{~g} / \mathrm{L}, 4 \mathrm{YP}$ medium, phosphate buffer $200 \mathrm{mM} \mathrm{pH} 6.0$ with final concentration $50 \mathrm{mM}$ and yeast cell $\mathrm{OD}_{600}=20$. Ethanol production was performed under oxygen limited conditions at $30^{\circ} \mathrm{C}$ with mild agitation $(150 \mathrm{rpm})$ in $100 \mathrm{~mL}$ bottles equipped with an outlet for $\mathrm{CO}_{2}$. The ethanol productions were checked for several sampling times $(0,2,4,6,8,12$, $24,48,72,96)$. The fermentation process was performed in triplicate, and the experimental data are average values. Respectively, two control systems devoid of yeast and enzyme were also prepared. Fermentation yield (g ethanol/g dry substrate) was calculated by the following equation:

$$
Y=\frac{E V}{M} \times 100
$$

where $E$ is the ethanol concentration $(\mathrm{g} / \mathrm{L}), V$ is volume of the reactor $(\mathrm{L})$, and $M$ is the substrate mass in the culture $(\mathrm{g})$. The maximum theoretical ethanol yield was calculated using the following equation:

$$
Y_{t h}=\frac{E_{\max }}{0.51 \times 1.111 \times d \times F} \times 100
$$


where, $E_{\max }=$ maximum produced ethanol $(\mathrm{g} / \mathrm{L}), d=$ dry weight of biomass $(\mathrm{g} / \mathrm{L}), F=$ cellulose fraction in biomass (for pretreated rice straw $=0.593$ ) [12], [13].

\section{E. Analysis}

The ethanol produce during the sampling times of fermentation were measured by gas chromatography - mass spectrometry (GC-MS) (QP2010UltraPlus, Shimadzu, Japan). This instrument equipped with the DB-FFAP column (60 m x $0.25 \mathrm{~mm}$ i.d., $0.5 \mu \mathrm{m}$ film thickness; Agilent $\mathrm{J} \& \mathrm{~W}$ GC Columns). The injection temperature was $250{ }^{\circ} \mathrm{C}$ and the flow rate of helium gas through the column was $1 \mathrm{~mL} / \mathrm{min}$. The column temperature was held at $40^{\circ} \mathrm{C}$ for $5 \mathrm{~min}$ isothermally before being increased by $30^{\circ} \mathrm{C} / \mathrm{min}$ to $230^{\circ} \mathrm{C}$, and held at $230^{\circ} \mathrm{C}$ for $10 \mathrm{~min}$. The interface and the ion source temperatures were $250^{\circ} \mathrm{C}$ and $230^{\circ} \mathrm{C}$, respectively.

\section{RESULTS AND DISCUSSION}

\section{A. Rice Straw Treatment Process}

The Indica IR.64 rice straw contains $38( \pm 0.5) \%$ cellulose, 24( \pm 0.5$) \%$ hemicellulose, $8( \pm 1) \%$ lignin and $18( \pm 0.5) \%$ ash, measured according to Sun et al., 1996 [14].

The first step in using rice straw for bioethanol production is size reduction through milling and sieving process (Fig. 1). Milling and size reduction were applied prior to enzymatic hydrolysis. This step can improve susceptibility to enzymatic hydrolysis by reducing the size of the materials and degree of crystallinity of lignocelluloses, which improves enzymatic degradation of rice straw toward ethanol [15], [16], [17]. Unlike woody biomass, the lignocellulosic materials from agricultural residues treatment does not requires as much energy as recalcitrant woody materials to reach size reduction for further hydrolysis process [18]. Size reduction enhanced the susceptibility of substrate to enzymatic hydrolysis. By applied the smallest straw particles in bioethanol production will increase the amount of glucose release for the hydrolysis process compared to untreated substrate [19].

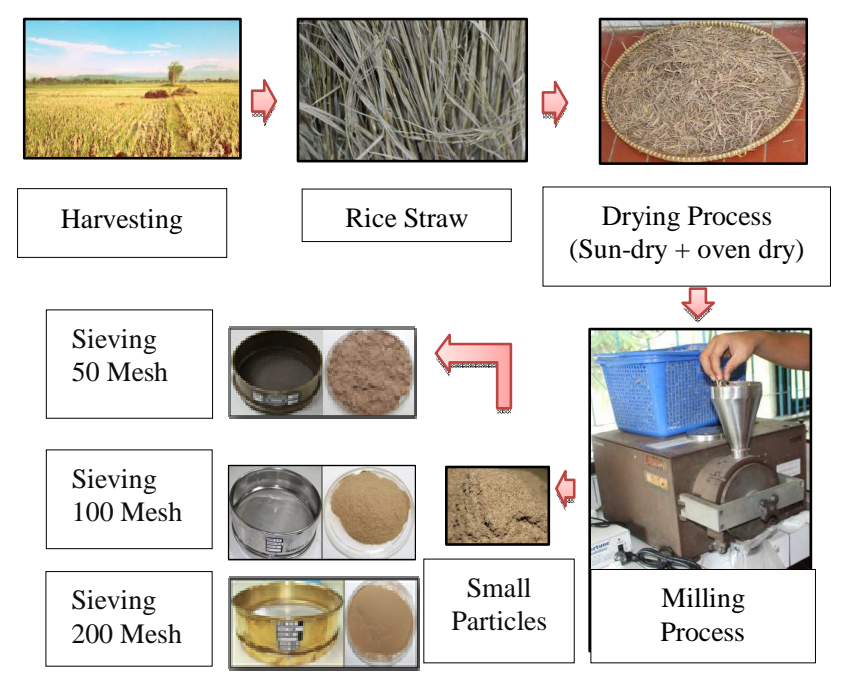

Fig. 1 Rice straw treatment process

\section{B. Crude Enzyme Production}

Cellulolytic microbes can produce cellulase enzymes which have ability to hydrolyze complex polysaccharides into simple molecules such as xylose and glucose as a monomer. Cellulase of microbial origin have been reported to be both induced as well as constitutive enzymes and are usually being secreted extracellular into the medium in which the microorganism is cultured (Fig. 2a).

Further quantitative analyses for these bacteria were conducted such as activity of cellulase, and the cellulase activity is $0.88 \mathrm{U} / \mathrm{mL}$ in the third day of fermentation. The optimal $\mathrm{pH}$ and temperature range for enzyme production from Saccharopolyspora flava and cellulase activity assay were 6 at room temperature (Fig. 2).

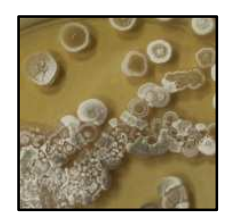

(a)

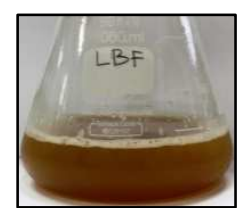

(b)

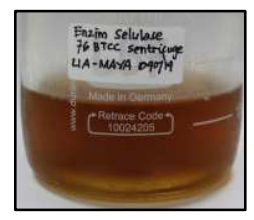

(c)
Fig. 2 (a) Saccharopolyspora flava (Actinomycetes: source of cellulase enzyme); (b) crude enzyme production by CMC substrate $0.5 \%, 30^{\circ} \mathrm{C}, 200$ rpm for 3 days; (c) cellulase enzyme centrifuged at $4^{\circ} \mathrm{C}, 10,000 \mathrm{rpm}, 10$ minutes.

\section{Yeast Cells}

The yeast strain used in this study is Saccharomyces cereviceae NBRC 1440 from NITE Biological Resource Center (NBRC) collection (Fig. 3). The cells were produced by using fermentation process and collected with centrifugation method at $5000 \mathrm{rpm}$ in 5 minute duration time and wash the cells using milli-Q water for 3 times for eliminate the remain medium. The final condition of yeast cells were adjusted at $600 \mathrm{~nm}\left(\mathrm{OD}_{600 \mathrm{~nm}}\right)$ for culture optical density equal to 20 as initial concentration. The low concentration of yeast cells has intention to determine the ethanol production based on short time duration of fermentation in optimum condition.

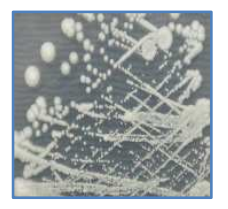

(a)

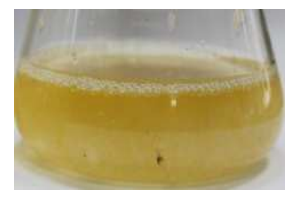

(b)
Fig. 3 (a) Saccharomyces cereviceae (NBRC-1440); (b) Yeast cell production at $30^{\circ} \mathrm{C}, 200 \mathrm{rpm}$ for 3 days.

\section{Bioethanol Production by Direct Saccharification and Fermentation}

Direct saccharification and fermentation (DSF) of Indica IR.64 rice straw was examined and compared with two type of control (systems devoid of yeast and enzyme). The experiment were carried out under anaerobic condition, 
where the cellulase crude enzyme and cellulosic substrates (rice straw) produced glucose from the cellulose and $S$. cerevisiae directly assimilated the glucose to bioethanol.

Bioethanol fermentation media were incubated at $30^{\circ} \mathrm{C}$ with agitation at $150 \mathrm{rpm}$ for several sampling times $(0,6$, $12,24,48,72,96 \mathrm{~h})$. The batch culture summarizes the important parameter of ethanol fermentation under the initial cell concentration and size of rice straw biomass (Fig. 5). As shown in Fig. 5, the faster rate of bioethanol production during DSF by $S$. cerevisiae was obtained within the first 12h. The experiments lasted for 4 days. However, the bioethanol concentrations decrease sharply after 2 days. It gives general conclusion that we need around 2 days to reach the maximum bioethanol concentration under anaerobic conditions (Fig. 5). In addition, it was found that the physical observation of the rice straw biomass has merge in second day (48h) of fermentation and indicating the enzyme works suitable in saccharification process.

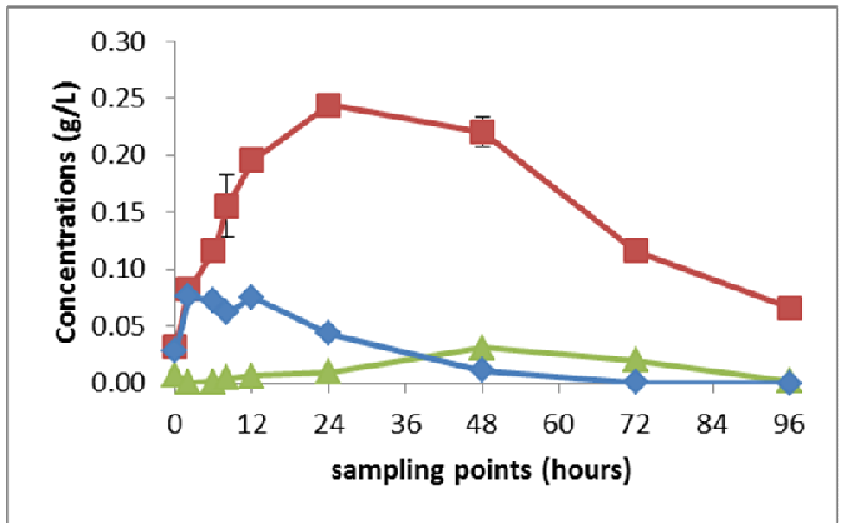

Fig.5 Ethanol concentrations ( $\square$ ), Control Without Yeast ( $)$ ), Control without Enzyme ( $\triangle$ )

The concentrations of bioethanol for several sampling times were measured with GC-MS by using isopropylalcohol as an internal standard. The maximum bioethanol concentration during DSF is $0.25 \mathrm{~g} / \mathrm{L}$ at $24 \mathrm{~h}$ as an optimum producing time. The chromatogram for GCMS analysis is shown in Fig. 6. The internal standard isopropyl-alcohol with concentration $100 \mathrm{ppm}$ was showed the positive peak of ethanol at retention time 8.712 and identified the amount of ethanol concentration at $0.25 \mathrm{~g} / \mathrm{L}$.

The fermentation yield and maximum theoretical ethanol yield were 10 and $14.88 \%$, respectively (calculated according to eq. 1 and 2). These values were 9.0 times higher than the control system. The low level of fermentation and theoretical ethanol yield might be due to untreated substrate (there are no appropriate pretreatment steps were applied to remove lignin from rice straw). Consequently, cellulose and hemicelluloses might still be bundled by a great amount of lignin, which would harm the enzymatic hydrolysis and ethanol fermentation [20]. In addition, the use of cellulase crude enzyme and rice straw as cellulosic substrate makes the saccharification and fermentation process could not optimum. However, some other factors may also affect the ethanol yield. Physical properties and cellulose microstructure are among the potential factors influencing enzymatic hydrolysis [21]. The direct saccharification and fermentation process is an extremely simple and environmentally-friendly system without harsh pretreatment.

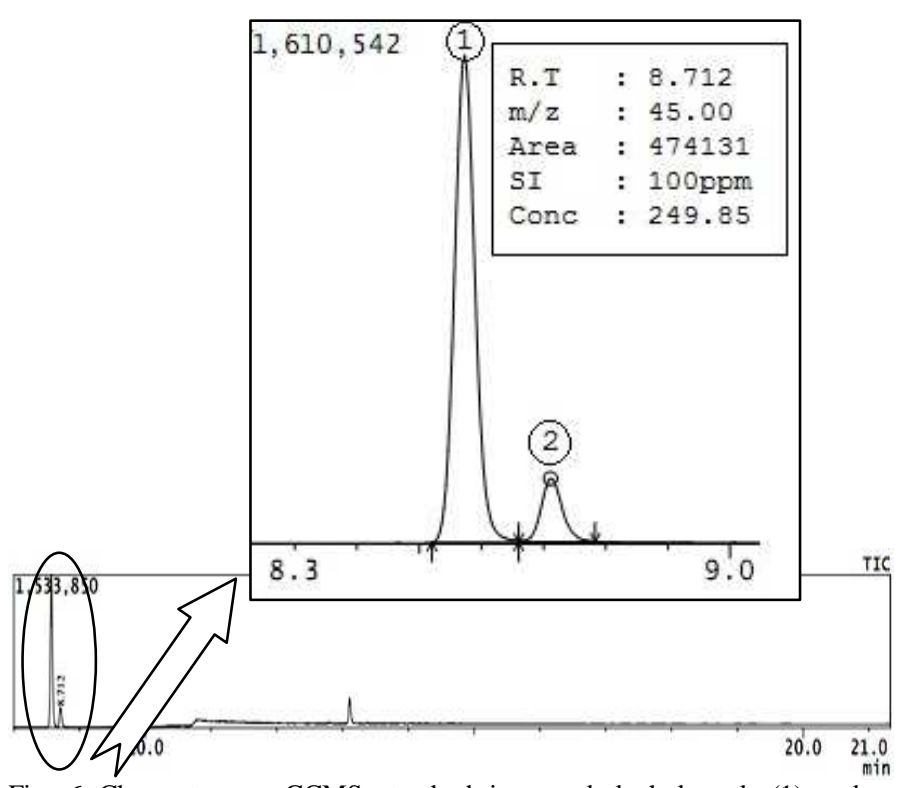

Fig. 6 Chromatogram GCMS standard isopropyl-alcohol peak (1) and ethanol peak (2).

Further integrated research on this process including the optimization/stabilization of feedstock quality and development of harvesting/storage technologies will be indispensable for commercialization of this technology.

\section{CONCLUSIONS}

Rice straw could provide us with a great opportunity for bioethanol production. In DSF process, the saccharification of rice straw by the enzyme and the subsequent fermentation of the sugars to ethanol by yeast take place in a single reactor. Despite of this system in this work gave the lower level yields, nevertheless, the value of yield which are greater than in the control system, shows the DSF process are potential to applied. In order to obtain high ethanol yield, the suitable pretreatment method, and the use of commercial enzyme are necessary to consider.

\section{ACKNOWLEDGMENT}

We are grateful to Dr. Puspita Lisdiyanti for kindly providing us with cellulotic isolate Saccharopolyspora flava from BTCC. This study was supported by grants from Center of Innovation, Indonesian Institute of Sciences (LIPI).

\section{REFERENCES}

[1] E. Ruiz, I. Romero, M. Moya, S. Sanchez, V. Bravo, E. Castro. "Sugar fermentation by Fusarium oxysporum to produce ethanol". World J. Microbiol Bioethanol vol. 23, pp. 259-267, 2007.

[2] B. Yang, C.E. Wyman, "Pretreatment: The key to unlocking low-cost cellulosic ethanol”. Biofuels. Bioprod. Bior. Vol. 2. Pp. 26-40. 2008.

[3] K. Karimi, G. Emtiazi, and M.J. Taherzadeh., "Ethanol production from dilute-acid pretreated rice straw by simultaneous saccharification and fermentation with Mucor indicus, Rhizopus oryzae, and Saccharomyces cerevisiae”, Enzyme and Microbial Technology, 40: 138-144. 2006. 
[4] G. Garrote, H. Dominguez, J.C Parajo. "Autohydrolysis of corncob: study of non isothermal operation for xylooligosaccharide production". J. Food. Eng. Vol. 52. Pp. 211-218. 2002

[5] B.I Maiorella, Ethanol Industrial Chemical. 861-914. 1983

[6] B.C Saha. Hemicellulose bioconversion. Ind. Microbiol. Bioethanol. Vol 30. Pp. 279-291. 2003.

[7] R. Zamora, J.A.S Crispin. "Production of an acid extract of rice straw". Acta. Cient.Venez. vol 46, pp 135-139. 1995.

[8] I.C Roberto, S.I Mussatto, R.C.L.B Rodriguez. "Dilute-acid hydrolysis for optimization of xylose recovery from rice-straw in a semi pilot reactor. Ind. Crops Prod. Vol 7. Pp 171-176. 2003.

[9] B.S Dien, M.A Cotta, T.W Jeffries., "Bacteria engineered for fuel ethanol production: current status". Appled Microbiology and Biotechnology. Vol 63. Pp 258-266. 2003.

[10] A.K Chandel, E.S Chan, R. Rudravaram, M.L Narasu,L.V Rao, L. Pogaku., Economics and Enviromental impact of bioethanol production technologies: an appraisal Biotechnology and Molecular Biology Reviews 2. Vol 1. Pp 14-32. 2007.

[11] G.L., Miller., Use of dinitrosalicylic acid reagent for determination of reducing sugar. Anal. Chem.3, 426-428. 1959.

[12] J. Shen, and F.A. Agblevor., "Ethanol production of semisimultaneous saccharification and fermentation from mixture of cotton gin waste and recycled paper sludge". Bioprocess and Biosystem Engineering, 34 (1): 33-43. 2011.

[13] K. Karimi, G. Emtiazi, M.J Taherzadeh. "Production of ethanol and mycelia biomass from rice straw hemicellulase hydrolyzate by Mucor indicus". Process Biochem. Vol. 41. Pp. 653-658. 2008

[14] R. Sun, J.M. Lawther, and W.B. Banks, " Fractional and structural characterization of wheat straw hemicelluloses. Carbohydrate Polymer. 29:325-331. 1996
[15] L.T. Fan, Y. Lee, and D.H. Beardmore, "Mechanism of the enzymatic hydrolysis of cellulose: Effect of major structural features of cellulose on enzymatic hydrolysis. Biotechnology Bioengineering, 22: 177-199. 1980.

[16] U. Mais, A.R. Esteghlalian, J.N. Sadler, and S.D. Mansfield, "Enhancing the enzymatic hydrolysis of cellulosic materials using simultaneous ball milling"., Appl Biochem Biotechnol. 815(32): 98100. 2002.

[17] Y. Zheng, H.M. Lin, and G.T. Tsao., "Pretreatment for cellulose hydrolysis by carbon dioxide explosion", Biotechnol. Progr. 14: 890896, 2008.

[18] A. Limayem, S.C Ricke., Lignocellulosic biomass for bioethanol production: Current perspectives, potential issues and future prospects, Progress in Energy and Combustion Science, vol. 38. Pp. 449-467, 2012.

[19] F. Talebnia, D. Karakeshev, I. Angelidaki., Production of Bioethanol from wheat straw: An overview on pretreatment, hydrolysis and fermentation. Bioresources Technology, Vol. 101.pp 4744-4753. 2010 .

[20] W. Cao, C. Sun, R. Liu, R. Yin, and X. Wu., "Comparison of the effects of five pretreatment methods on enhancing the enzymatic digestibility and ethanol productionfrom sweet sorghum bagasse", Bioresource Technology, 2012.

[21] T.H. Kim, J.S. Kim, C. Sunwoo, and Y.Y. Lee., "Pretreatment of corn stover by aqueous ammonia". Bioresource Technology, 90: 3947. 2003. 